\title{
CONSTRAINTS TO UTILIZATION OF IMPROVED PROCESSING TECHNOLOGIES AMONG CASSAVA PROCESSORS IN OYO STATE, NIGERIA
}

\author{
Ewebiyi, I.O. ${ }^{1 *}$, Ikotun, T.O. ${ }^{1}$, Olayemi, O.O. ${ }^{2}$ \\ CUganda Martyrs University
}

\begin{abstract}
This study investigated the constraints associated with utilization of improved processing technologies among cassava processors in Oyo State, Nigeria. A structured questionnaire was used to collect data from a random sample of 176 respondents. Data was analyzed using descriptive statistics and Pearson Product Moment Correlation. The findings were that most (56.8\%) of the respondents had a positive attitude towards utilization of mechanical grater, screw press hydraulic and Hammer mill technologies. However, inadequate funds, lack of technical know-how, lack of information, high cost of purchase and inadequate engineers for the improved processing technologies were identified as severe constraints militating against utilization of improved processing technologies. Significant relationship was established between these constraints and utilization of the improved processing technologies. It is recommended that government 1) builds factories that will lower the cost of the technologies; and 2) ensures that research institutes, departments of Agricultural engineering in universities and polytechnics and adult education programs in the community are adequately funded to promote knowledge of the technologies.
\end{abstract}

Keywords: Cassava processors, utilization, improved processing technologies, constraints, Oyo state

CONTRAINTES A L'USAGE DES TECHNOLOGIES TRAITANTES AMELIOREES PARMI LES TRAITANTS DU MANIOC DANS L'ETAT D'OYO, NIGERIA

Résumé

Cette étude a examiné les contraintes associées à l'usage des technologies traitantes améliorées parmi les traitants du manioc dans l'état d'Oyo au Nigeria. Un questionnaire structuré fut utilisé pour la collecte de données provenant de 176 enquêtés hasardement sélectionnés du champ d'étude. Les données ainsi collectées furent analysées par moyen de statistiques descriptives (telles que le comptage de fréquence, le pourcentage et la moyenne) ainsi que les statistiques inferentielles. La Corrélation du Moment Produit de

\footnotetext{
${ }^{1}$ Tai Solarin University of Education, Ogun State, Nigeria, * tayoewebiyi@ yahoo.com

${ }^{2}$ Federal College of Forestry, Ibadan, Oyo State, Nigeria
} 
Pearson (CMPP) fut employée pour déterminer la relation entre contraintes et usage des technologies traitantes améliorées parmi les traitants du manioc dans le champ d'étude. Les résultats de l'étude ont démontré que l'âge moyen d'enquêtés était de 41.23 ans et que plus d'un quart d'enquêtés (33.0\%) avaient six à dix ans d'expérience dans le traitement du manioc. De surcroit, les résultats ont révélé que la plupart d'enquêtés (56.8\%) avaient une attitude favorable envers l'usage des technologies traitantes améliorées de rappe mécanique, presse-vis hydraulique et moulin-marteau. Des fonds inadéquats, le manque du savoir-faire technique, le manque d'information, le coût élevé d'achat, et les ingénieurs inadéquats concernant les technologies traitantes améliorées ont été identifiés par les enquêtés comme sérieuses contraintes militant contre l'usage des technologies traitantes améliorées. Une relation significative existait aussi entre contraintes $(\mathrm{r}=-0.189, \mathrm{p}=0.012)$ auxquelles les enquêtés font face et leur usage des technologies traitantes améliorées. L'étude a recommandé que le gouvernement construise les usines ou industries où les technologies traitantes améliorées seraient fabriquées à coût bas, que les instituts de recherche et département d'ingénierie agronome dans les universités et écoles polytechniques soient financés adéquatement, ainsi que les programmes d'alphabétisation d'adultes dans les communautés de traitants du manioc pour surmonter le défi d'analphabétisation et la saisie du savoir-faire technique concernant les opérations technologies. Tout ceci va renchérir l'usage effectif des technologies traitantes améliorées parmi les traitants du manioc dans le champ d'étude — une chose qui, en long terme, pourra se traduire en haute productivité, augmentation de revenus, et conditions de vie en mieux.

Mots clés : Traitants du manioc, usage, technologies traitantes améliorées, contraintes, l'état d'Oyo

\section{Introduction}

Cassava (Manihot esculenta) is one of the world's most important food crops. In Nigeria, as in most developing Countries, it is one of the most important carbohydrate sources (Akinnagbe 2010). It is a widely grown crop in most countries in the tropical region of Africa and Asia; and ranks as one of the main crops in the tropical countries (Katz as cited in Okereafor, Aye and Ezihe 2018). It is the most important staple food crop in Nigeria and in recent years has become an important industrial raw material for food and starch based industries. Earlier, cassava based farming communities coped better in hunger stressed times and uncomfortable situations Emmanuel (2008). Cassava is widely cultivated in Nigeria where it plays a vital role in the food security of the rural economy because of its capacity to yield under marginal soil conditions and drought (Ezedimma 2006). Thailand is the leading exporter of cassava starch and cassava pellets for animal feed; Indonesia's exports are primarily in the area of cassava pellets and chips for animal feed while Costa Rica, normally the third largest exporter, exports fresh cassava for human feed. Between 1900 and 1988, worldwide Cassava production increased by $12.5 \%$ (FAO, 2005). In Nigeria, cassava is grown in 24 of the country's 36 states. The major states are Anambra, Delta, Edo, Benue, Cross River, Imo, Oyo and River, and to a less extent Kwara and Ondo (IITA 1992).

Cassava has also become economically important in several tropical countries such as Congo, Coted'ivore, Ghana, Nigeria, Tanzania and Uganda where the Carbohydrate content of its enlarged root is consumed in diversified forms. Owing to its short shelf life and high perishability of harvested fresh roots, cassava requires immediate processing of the roots into more stable and widely utilizable products (Radindran and Kenkpen 2006). The perishability problem of Cassava roots has been partially resolved in certain areas by processing cassava root into a variety of dried products such as flour, starch, and chips (Nweke 2004). Cassava processing essentially involves conversion of the fresh root into other forms acceptable to the consumers. Cassava can be processed into many primary products such as garri, starch, flour, and fufu meal.

Since past years, cassava production and processing has been facing a lot of constraints. Unfortunately, no supply chain structures exist for the commercialization of supplying cassava products as primary sources of raw materials for agro-industries with aid of improved processing technology. At farm level, 
the production costs for cassava in Nigeria were high relative to other countries. Production was not oriented towards commercialization, but instead farmers produced and processed cassava as a subsistence crop (Ugwu 2008). A major constraint of cassava production is the rapid post-harvest deterioration of its roots which usually prevents their storage in the fresh state for more than a few days before processing (Okezie and Kosikowski as cited in Tonukari 2004).

Research institutes such as Product Development Agency (PRODA), International Institute of Tropical Agriculture (IITA), National Root Crops Research Institute (NRCRI), Umudike and Agricultural Engineering Departments in several Universities and Polytechnics in Nigeria have developed many mechanized units to fabricate processing machines designed to ease cassava processing. Several models and variations of cassava processing technologies are available in the market (Taiwo as cited in Fefa et al. 2014) and include among others, the peeling machine, cassava chopping machine, grafting machine, hammer mill, hydraulic press, dryers and pelletizer.

Technologies for root and tuber crop processing were developed by the Food Research Institute to make dehydrated products such as fermented cassava meals, cassava chips and flours ready for transfer commercialization and for enhanced food security. These are intermediate products for the preparation of various traditional foods and recipes. In addition, convenience foods such as $f u f u$ (pounded root and tuber crops) powders had been developed to facilitate the preparation of $f u f u$ in urban homes without the requirement for the highly perishable fresh root and tuber crops. Other cassava based products included high protein gari prepared from cassava and soybean with proper packaging for sale in urban centers' supermarkets. The high quality cassava flour was the most recent research output of the Food Research Institute in cassava processing, popular for the versatility of its application as an industrial raw material. This intermediate cassava flour could be used for adhesives in the plywood industry, for the formulation of composite flours in the bakery industry, and for the production of cassava glucose syrup for use in the confectionery industry (Quaye et al. 2009). Cassava processing technologies aimed at easing the process and mitigating the perishability problem of cassava roots. They also helped in diversifying the use of cassava, its adoption and effective utilization in Nigeria, particularly in Oyo state.

According to Akinola et al. (2015), studies have been conducted on cassava as a crop in general. However, much has not been done on constraints militating against effective utilization of improved processing technologies of cassava. It is against this backdrop that this study examined constraints to utilization of improved processing technologies among cassava processors in Oyo State, Nigeria. This paper has generated information about processors' constraints toward utilization of improved processing technologies and such information could be used by extension agents and engineers to design appropriate messages aimed at enhancing attitudes towards such technologies. The specific objectives were to: Identify socio-economic characteristics of cassava processors in Oyo State, Nigeria; To determine respondents' attitude towards utilization of improved processing technologies in the study area; and to identify respondents' constraints to utilization of improved processing technologies.

\section{Hypothesis of the study}

HO - There is no significant relationship between constraints faced by the respondents and their utilization of improved processing technologies

\section{Methods}

This study was carried out in Oyo State, one of the six states in Southwestern Nigeria. The economy of the state is based on agriculture and the main occupation of the inhabitants is farming. It is located between Latitude $7^{0} 2^{1}$ and $9^{0} 1^{1}$ North of the Equator and between Longitude $2^{0} 5^{1}$ and $4^{0} 3^{1}$ East of the Greenwich Meridian. The mean annual rainfall ranges from 56 inches in the South and 46 inches in the North. The Climate in the state favors the cultivation of crops like maize, yam, cassava, millet rice, 
plantains, cocoa, oil palm, and cashew. The people of Oyos engage in other activities such as transport operation, blacksmithing, tailoring and carpentry. The state is homogenous in terms of language and comprises the Oyos, the Ibadans and Ibarapas, all belonging to Yoruba family and speak Yoruba language.

Multistage sampling procedure was used to select 176 respondents for the study. Simple random technique was used to select two (Ogbomoso and Ibadan/Ibarapa) out of four Agricultural Development Program (ADP) zones in Oyo state. Purposive Sampling technique was used to select local government and communities that were predominantly noted for cassava production and processing from the selected two zones and 50\% of registered cassava processors were randomly picked from the selected communities through the Department of Agriculture and Health at the Local Government Headquarters in Arowomole and Eruwa respectively.

The survey research design was employed and data was collected through structured questionnaires which were administered to the respondents. The information collected on socio-economic characteristics of respondents included age, sex, religion, marital status, education, household size and experience. Other information included respondents' attitudes to and constraints faced by the processors in utilization of improved processing technologies.

In trying to obtain attitudes towards the utilization of improved processing technologies, a 4 point Linkert-type scale with four response options ( $4=$ Strongly agree (SA), $3=$ Agree (A), 2 = Disagree (D), and $1=$ Strongly disagree (SD) was used. The values on the Linkert- type scale were summated to 10, and later divided by 4 , to get a mean score of 2.5. Then respondents' mean scores were obtained for each response item such that any one higher or equal to 2.5 was regarded as a favorable attitude. Also in order to obtain constraints to utilization of improved processing technologies, a 3-point scale with response option ( $3=$ Severe constraint, $2=$ Mild constraint and $1=$ Not a constraint $)$ was used. The values on the 3 -point scale were summated to 6 and later divided by 3 , to get mean score of 2.0. Then respondents' mean scores were obtained for each response item such that any one higher or equal to 2.0 was regarded as a total constraint.

Descriptive statistics such as frequency counts, percentages and mean were used to analyze objectives i iii of the study while Pearson Product Moment Correlation (PPMC) was used as inferential statistic at 0.05 significant level to determine the relationship between constraints and utilization of improved processing technologies among cassava processors in the study area. The ranking was done by the highest mean value in ascending order.

\section{Findings}

Table 1: Socio-economic Characteristics of the Respondents

\begin{tabular}{llll} 
Variable & Frequency & Percentage & Mean \\
\hline Age (years) & 3 & & \\
$11-20$ & 27 & 1.7 & 41.23 \\
$21-30$ & 65 & 15.3 & \\
$31-40$ & 44 & 36.9 & \\
$41-50$ & 28 & 25.0 & \\
$51-60$ & 9 & 15.9 & \\
Above & & 5.1 & \\
& & & \\
Sex & 43 & 24.4 & \\
Male & 133 & 75.6 & \\
Female & &
\end{tabular}




\section{Religion}

Christian

Muslim

Traditional

\section{Marital Status}

Single

Married

Divorced

Separated

Widowed

\section{Education}

No formal education $\quad 20$

11.4

Vocational education 2

Primary education $\quad 62$

1.1

Secondary education

Tertiary education

\section{Household size}

$1-3$

$4-6$

$7-9$

$10-12$

Above 12

\section{Processing Experience}

$1-5$

$6-10$

$11-15$

$16-20$

$21-25$

\section{Income}

$\begin{array}{llll}\$ 50 & = & 60 & 34.1 \\ \$ 50.10-\$ 100 & = & 89 & 50.6 \\ \$ 100.10-\$ 150 & = & 23 & 13.1 \\ \$ 150.10-\$ 200= & 03 & 1.7 \\ \text { Above } \$ 200 & = & 1 & 0.6\end{array}$

$41 \quad 23.3$

$102 \quad 58.0$

$28 \quad 15.9$

$1-0.6$

$4 \quad 2.3$

$52-29.5$

$58 \quad 33.0$

$31-17.6$

$31-17.6$

$4 \quad 2.3$

Source: Field Survey, 2017.

Table 2a: Respondents' Attitude to Utilization of Improved Processing Technologies

\begin{tabular}{llllll}
\hline Attitudinal Statements & SA & A & D & SD & Mean \\
\hline Modern cassava processing method saves time & 66.5 & 26.1 & 6.8 & 0.6 & 3.52 \\
Spare parts of improved processing technologies are not available & 2.3 & 19.9 & 46.0 & 31.8 & 1.77 \\
Improved processing technologies increase production & 69.9 & 22.7 & 7.4 & - & 3.55 \\
Funds are not a problem to acquire improved technologies & 8.0 & 4.0 & 13.6 & 74.4 & 2.06 \\
\hline
\end{tabular}




\begin{tabular}{llllll}
\hline In the operation of improved technologies, injuries are sustained & 25.0 & 69.9 & 10.8 & 2.3 & 3.01 \\
I'm not feeling comfortable using improved technologies & 4.5 & 5.7 & 41.3 & 48.3 & 1.73 \\
Fluctuation of power supply hinders the use of improved technologies & 9.1 & 9.7 & 23.9 & 57.4 & 2.04 \\
Use of improved technologies reduces the use of hired labor & 8.0 & 19.3 & 68.8 & 4.0 & 1.67 \\
I will recommend improved technologies to my friend & 58.0 & 29.0 & 11.9 & 1.1 & 3.33 \\
Hand grating is preferred to improved technologies & 16.5 & 13.1 & 52.3 & 18.2 & 1.94 \\
Stone pressing as a traditional technique is cheaper and better than & 71.0 & 21.6 & 6.3 & 1.1 & 3.57 \\
improved technologies & & & & &
\end{tabular}

Source: Field Survey 2017.

Table 2b: Categorization of Respondents by their Attitude

\begin{tabular}{lllllll}
\hline Category & F & \% & Mean & SD & Minimum & Maximum \\
\hline Favorable & $\mathbf{1 0 0}$ & 56.8 & 28.20 & 5.03 & 11.00 & 41.00 \\
Unfavorable & $\mathbf{7 6}$ & 43.2 & & & & \\
\hline Source: & & & &
\end{tabular}

Source: Field survey 2017.

Table 3: Respondents' Constraints to Utilization of Improved Processing Technologies

\begin{tabular}{|c|c|c|c|c|c|}
\hline Constraint & $\begin{array}{c}\text { Severe } \\
\text { Constraint }\end{array}$ & $\begin{array}{c}\text { Mild } \\
\text { Constraint }\end{array}$ & $\begin{array}{c}\text { Not a } \\
\text { Constraint }\end{array}$ & Mean & Rank \\
\hline Inadequate funds & 91.5 & 5.1 & 3.4 & 1.89 & 1 \\
\hline Lack of technical knowhow & 88.6 & 8.0 & 3.4 & 1.85 & 2 \\
\hline Lack of information & 84.1 & 13.1 & 2.8 & 1.81 & 3 \\
\hline High cost of purchase & 83.0 & 13.6 & 3.4 & 1.80 & 4 \\
\hline $\begin{array}{l}\text { (Manihot esculenta) Inadequate } \\
\text { Engineers }\end{array}$ & 80.1 & 17.6 & 2.3 & 1.78 & 5 \\
\hline Lack of maintenance & 75.0 & 22.7 & 2.3 & 1.73 & 6 \\
\hline $\begin{array}{l}\text { Scarcity of spare parts for } \\
\text { maintenance }\end{array}$ & 52.8 & 45.5 & 1.7 & 1.51 & 7 \\
\hline Inadequate extension agents & 53.4 & 42.0 & 4.5 & 1.49 & 8 \\
\hline $\begin{array}{l}\text { Ineffective cassava processors' } \\
\text { Association }\end{array}$ & 47.2 & 44.9 & 8.0 & 1.39 & 9 \\
\hline Conservatism & 40.3 & 36.4 & 23.3 & 1.17 & 10 \\
\hline Poverty & 47.7 & 32.4 & 19.9 & 1.13 & 11 \\
\hline $\begin{array}{l}\text { Government paper policy on } \\
\text { agriculture }\end{array}$ & 21.6 & 57.4 & 21.0 & 1.01 & 12 \\
\hline Political instability & 10.2 & 64.2 & 25.6 & 0.84 & 13 \\
\hline Lack of computer literacy & 10.2 & 60.8 & 29.0 & 0.81 & 14 \\
\hline Natural disaster & 4.5 & 64.2 & 31.3 & 0.73 & 15 \\
\hline Epileptic Electricity power supply & 14.2 & 33.0 & 52.8 & 0.61 & 16 \\
\hline Culture & 2.3 & 26.1 & 71.6 & 0.31 & 17 \\
\hline Religion & 2.3 & 26.7 & 71.0 & 0.31 & 17 \\
\hline
\end{tabular}

Source: Field survey 2017. 
Table 4: Pearson Product Moment Correlation (PPMC) Between Constraints and Respondents' Utilization of Improved Processing Technologies

\begin{tabular}{llll}
\hline Variable & R & P & Decision \\
\hline Constraints & -0.189 & 0.012 & Significant \\
\hline
\end{tabular}

Source: Field survey 2017.

\section{Results and Discussion}

Results in Table 1 revealed that the mean age of the respondents was 41.23. This implies that most respondents were in their active age, expected to position themselves favorably towards utilizing improved processing technologies for their cassava processing. This finding is in line with that of Akinbile (2007) and Adedeji et al. (2013) who carried out similar studies in Ogun State, Nigeria and reported a mean age of 41.23 with the age range of 20 - 50 years that constituted the active force of the study population. Results of analysis on respondents' sex in Table 1 revealed that $24.4 \%$ were males, while $(75.6 \%)$ were females. This implied that females involved more in cassava processing than males in the study area.

Result further showed that $60.8 \%$ of the respondents were Christians, 36.4\% Muslim and $2.8 \%$ traditional believers. Religion is one of the major identifiers of Nigerians. Oyesola and Ademola (2011) asserted that religious institutions can assist in making information available most especially in rural areas on awareness and utilization of improved processing technologies among cassava processors. Results in Table 1 also revealed that most respondents $(75.6 \%)$ were married. This connotes that the marriage institution is still highly esteemed in the society because it is evidence of being responsible. This result is also in tandem with the report of Ewebiyi and Arimi (2013) who submitted that the marriage institution played a key role in the livelihoods of rural dwellers in Ogun State, Nigeria.

Concerning educational status of the respondents, analysis revealed that nearly half of the respondents (45.5\%) had secondary education, $(35.2 \%)$ primary education, $(11.4 \%)$ had no formal education $(6.8 \%)$ had tertiary education while infinitesimal number of respondents $(1.1 \%)$ had vocational education. This implies that education is a major problem confronting respondents in the study area. This finding is in agreement with the summation of Fatunla, (2006) that low levels of education contributed to low capital based technological skills, which could consequently lead to low income and inability of cassava processors to buy available improved processing technologies.

The results further showed that most (58.0\%) of the respondents had four to six persons' households. This implied that the household size among the respondents was fairly large, and probably most of them rely on family labor. This result corroborated with the findings of Oluwatayo (2009) who carried out a study on livelihood diversification among rural households in Nigeria and reported that household size among rural farm families was usually large.

Analysis also revealed that more than a quarter $(33.0 \%)$ had six to ten years of experience in cassava processing. Furthermore, monthly incomes earned by $50.6 \%$ of the respondents in the study area ranged between \$50.10- \$100. This implied that respondents were low income earners likely to face challenges when it came to acquiring improved processing technologies. This agreed with the findings of FAO (2001) that rural dwellers were characterized by meager incomes that often predisposed them to poverty and unimproved standards of living due to low standards of processing technologies used.

In Table 2a, analysis revealed that most respondents $69.5 \%, 66.9 \%$ and $58.0 \%$ strongly agreed that modern cassava processing technologies eased and increased production, and saved processing time and were ready to recommend the technologies to their friends respectively. This was confirmed in Table $2 b$ 
as majority of the respondents $(56.8 \%)$ had favorable attitudes while $(43.2 \%)$ had unfavorable attitudes towards utilization of improved processing technologies. The implication was that respondents could be willing or eager to utilize improved processing technologies due to the benefits derivable from them.

Analysis of results in Table 3 showed that most respondents $91.5 \%, 88.6 \%, 84.1 \%, 83.0 \%$, and $80.1 \%$ observed inadequate funds, lacked technical know- how, inadequate information, high cost of purchase and inadequate engineers as severe constraints to utilization of improved processing technologies. Also $64.2 \%$ and $60.8 \%$ of the respondents respectively identified political instability, natural disaster, and lack of computer literacy as mild constraints militating against utilization of improved processing technologies among cassava processors in the study area. This implied that constraints faced by the respondents posed a significant threat to their adoption and utilization of improved processing technologies. This result was corroborated by Abdoulaye et al. (2014) and Fefa et al. (2014) who respectively carried out similar studies in Benue state, Nigeria and identified inadequate funds, lack of information, lack of technical know-how and high cost of purchase as severe constraints militating against utilization of improved processing technologies among cassava processors.

Table 4 revealed the results of correlation between cassava processors' constraints and their utilization of improved processing technologies which shows that there is significant negative relationship between constraints $(\mathrm{r}=-0.189, \mathrm{p}=0.012)$ faced by the respondents and their utilization of improved processing technologies. This implies that constraints faced by the respondents may pose a significant threat to their utilization of improved processing technologies in the study area.

\section{Conclusion and Recommendations}

The study examined the constraints encountered by cassava processors in utilizing improved processing technologies in Oyo State, Nigeria. Result showed that most respondents were females. They were mostly married but with low level of education and incomes but with wider experience in cassava processing. Majority had favorable attitudes towards utilization of improved processing technologies. Inadequate funds, lack of information, lack of technical knowhow, high cost of purchase and inadequate engineers were the severe constraints militating against cassava processors' utilization of improved processing technologies in the study area. A significant relationship also existed between respondents' constraints and their use of improved processing technologies leading to the rejection of the hypothesis of the study. Based on the findings, the following recommendations were put forward for increased adoption of improved technologies:

(i) Government should build factories or industries where improved processing technologies could be fabricated at low cost.

(ii) Research institutes and engineering departments of universities and polytechnics should be adequately funded and have memorandum of understanding (MOU) (Partners) with private organizations to come up with quality and standard cassava improved processing technologies to ease processing and increase productivity.

(iii) Adult literacy programs should be organized with in the communities of cassava processors to surmount illiteracy problems and enhance technical knowhow of technology operations.

\section{References}

Abdoulaye, T, Abass, A, Maziya-Dixan, B, Tarawali, G and Ayedun, B 2014, Awareness and adoption of improved cassava varieties and processing technologies in Nigeria, Journal of Development and Agricultural Economics, vol. 6, no. 2, pp. 67-75.

Adedeji, TO, Nosiru, MO, Akinsulu, AA, Ewebiyi, IO, Abiona, BG and Jimoh, TS 2013, Adoption of New Rice for Africa (NERICA) technology in Ogun State, Nigeria, Journal of Development and Agricultural Economics, vol. 5, no. 9, pp. 365-371. 
Akinbile, LA 2007, Social impact of limestone exploitation in Yewa North Local Government Area of Ogun State, Nigeria, Pakistan Journal of Social Sciences, vol. 1, no. 6, pp. 107-111.

Akinnagbe, OM 2010, Constraints and Strategies towards Improving Cassava Production and Processing in Enugu North Agricultural zone of Enugu State, Nigeria. Bangladesh J. Agril. Res, vol. 35, no. 3, pp. 387-394.

Akinola, AA, Alene, AD, Adeyemo, R, Sanogo, D, Olarenwaju, AS, Nwoke, C, Nziguheba, G, Diels, J 2015, "Determinants of Adoption and Intensity of use of Balanced Nutrient Management Systems. Technology in the Northern Guinea Savanna of Nigeria" Q. J. Int. Agric, vol. 49, no. 1, pp. 25-45.

Ewebiyi, IO and Arimi, K 2013, Gender differentials in adoption of improved cassava production techno in Ogun State, Nigeria, Journal of Agricultural Science and Policy Research, vol. 3, no. 2, pp. 110.

Emmanuel M. 2008, Guide to identification and control of cassava disease, Crop Research Institute, Kumasi, Ghana.

Ezedimma, C Dixon, L, Sanni, R, Okechukwu, M, Akoroda, J and Okoro, E 2006, Trends in cassava production and commercialization in Nigeria, International Institute of Tropical Agriculture.

FAO 2005b. A historical background on food aid and key milestones. Committee on commodity problems, sixty-fifth session, CCP/05/CRS,6, Rome, 11-13.

Fatunla, GT 2006, Entrepreneurship for economic development, Inaugural lecture series 27, Federal University of Technology, Akure, Nigeria, pp. 1-4.

Fefa, J, Obute, O and Ucherwuhe, SI 2014, Cassava processing technology adoption and poverty reduction among operators in Benue state, Nigeria, International Journal of Science and Research, vol. 2, no. 10, pp. 309-317.

International Institute of Tropical Agriculture (IITA) 1992, Cassava utilization storage and small scale processing. Quarterly Bulletin.

Nweke, F 2004, New challenges in the cassava transformation in Nigeria and Ghana, Environmental Technology Division Discussion Paper No. III, IFPRI Washington DC.

Okereafor, V.U., Aye, G.C and Ezihe, J.A.C (2018). Marketing Efficiency of Retailers and Wholesalers of processed Casssava Products in Imo State, Nigeria. Journal of Agricultural Economics Extension \& Science (JAEES) vol. 4, no. 1, pp. 131-145.

Oluwatayo, IB 2009, Poverty and income diversification among households in rural Nigeria, a gender analysis of livelihoods patterns. A conference paper presented at the $2^{\text {nd }}$ Institute of Estudos Sociaise Economics (IESE) Conference on Dynamics of Poverty and Pattern of Economic Accumulation in Maputo, Mozambique, 22-23 April, 2009, Conference paper No. 41.

Oyesola, OB and Ademola, AO 2011, Livelihood in University of Ibadan Social Laboratory in Ile-Igbo Community of Osun State, Nigeria, Journal of Human Ecology, vol. 34, no. 2, pp. 91-100.

Quaye, W., Gayin, J., Yawson, I. and Plahar, W.A (2009). Characteristics of various cassava processing methods and the Adoption Requirement in Ghana, Journal of Root Crops, vol. 35, no. 1, pp. 5968.

Ravindran, S. and D. Kenkpen, 2006, Cassava production and utilization in Liberia, Annual Report of the Central Agricultural Research Institute, Liberia, pp. 1-16.

Tonukari, NJ 2004, Cassava and the future of starch, Electronic Journal of Biotechnology, vol. 7 No. 1, pp 1-4. http://dx.doi.org/10.2225/vol7-issue1-fulltext-9

Ugwu, CC 2008, Gender Roles in Cassava Production and Processing in Enugu North Agricultural Zone of Enugu State, Nigeria. B. Agriculture Thesis, Department of Agricultural Extension, University of Nigeria, Nsukka. 